\title{
Corporate Villains: taking the bore out of law
}

\author{
Craig Cameron \\ Department of Accounting, Finance and Economics \\ Griffith University \\ Parklands Drive, Southport \\ E: craig.cameron@griffith.edu.au
}

\section{Introduction}

Corporate law teachers face an enormous challenge - how does one take an artificial creature known as the company and make it "hot" (i.e. attractive) for a growing number of Generation Y students? "Corporate Villains" is an innovative approach to teaching through storytelling which promotes engagement. The stories of infamous corporate identities such as Alan Bond, Peter Foster, Rene Rivkin and Christopher Skase are told, with particular emphasis on the legal ramifications of their exploits. Corporate villains engage students by contextualising the curriculum and introducing the human dimension to company law. This brief note addresses themes including popular culture, villainy, storytelling and student engagement. I provide quantitative and qualitative data to support the influence of corporate villains on student learning. However with such a focus on villains, am I simply ignoring the importance of our corporate heroes?

\section{Learning Issue}

Business (or non-law) students have expressed concern about the potential for company law to be "dull", "dry" and "not very interesting". I I suggest this initial concern is based on a perception that company law lacks a human element. The company is the creation of a complex regulatory regime that numbers in the thousands of pages and its consolidated text represents a visual nightmare for commencing students. These students have typically completed an introductory business law course which involved tales of: sex (labour law); drug and alcohol fuelled behaviour, botched medical procedures and acts of random stupidity (tort law); and deceptive advertising and sales practices (trade practices law). Though contract law may be dry, students are at least attuned to the legal issues raised because they encounter contracts in their daily lives. Such a cursory inspection of the introductory law curriculum highlights the fundamental challenge of teaching company law - many students without a business background cannot relate to its subject matter, in part because they are unable to visualise and identify with the issues regulated by company law. ${ }^{2}$ I addressed that challenge in part by introducing storytelling and villainy into the company law curriculum.

\section{Villainy and Storytelling}

Storytelling is a teaching method designed to promote student engagement and deepen student understanding of the subject matter. ${ }^{3}$ Legal storytelling involves the use of fiction or non-fiction stories in the classroom and can take a variety of forms including: background information of parties in decided cases; stories about personal experiences in the legal world; and discussion of law-related movies, music and literature. ${ }^{4}$ The storytelling approach is particularly beneficial for the large proportion of business students in which English is their second language ('ESL students'). As

\footnotetext{
${ }^{1}$ All quotes are derived from Student Evaluation of Teaching and Student Evaluation of Course responses for Company Law in the years 2008 to 2010 unless otherwise stated. Quotes can be produced on request.

2 B Dyer, 'Making company law more practical and more theoretical - curriculum design' (1995) 5 Australian Journal of Corporate Law 281 at 284-85.

3 M. Blissenden, 'Using storytelling as a teaching model in a law school: the experience in an Australian context' (2008) 16(1) Legal Education Digest 37

${ }^{4} \mathrm{~K}$ P Lewinbuk, 'Can successful lawyers think in different languages? Incorporating critical strategies that support learning lawyering skills for the practice of law in a global environment' (2008) 7 Richmond Journal of Global Law and Business 1 at 8-9.
} 
Lewinbuck notes, "storytelling is something everyone can relate to. The law, in contrast, is not". The story can promote more open dialogue in the classroom through the sharing of experiences and assists ESL students in learning both the law and culture. ${ }^{6}$

The corporate villains concept draws on the obsession of popular culture with villains. Unlike the hero, the villain in popular culture can attract a broad spectrum of emotional responses from admiration to condemnation. Think of the exploits of Frank Abagnale, the convicted fraudster, imposter and escape artist popularised in the 2002 film "Catch me if you can", mob boss Tony Soprano in the television series "The Sopranos", Hannibal Lecter, a cannibalistic serial killer played by Sir Anthony Hopkins in the "Silence of the Lambs" and even sensationalist judge Simon Cowell in the "X Factor" and "American Idol". These are flawed, but fascinating fictional and non-fictional characters that popular culture loves or loves to hate. Villains cast in corporate roles also pervade popular culture. Who can forget the "greed is good" mantra of Gordon Gecko played by Michael Douglas in "Wall Street", Miranda Priestly, the icy editor-in-chief of Runway Magazine played by Meryl Streep in "The Devil Wears Prada" and even Tilda Swinton's Oscar award winning performance as the ruthless corporate lawyer Karen Crowder in the film "Michael Clayton"? As in popular culture, the purpose of introducing villains in company law is to engage the audience and thereby provide them with a positive experience. The sections which follow detail the corporate villains concept and the positive learning experiences of company law students.

\section{Corporate Villains: Learning Activity}

The corporate villains concept was implemented in Company Law, a second year course within the Bachelor of Commerce degree at Griffith University and a compulsory course for students completing the accounting major. I include a photograph or "mugshot" of a corporate villain on the cover of each week's reading guide. The photograph enables students to put "a face to a case", thereby humanising company law for students. Rene Rivkin is not just a defendant in an insider trading case, but was involved in the company Offset Alpine, the subject of a mysterious fire which engulfed its manufacturing plant in 1993. Bond is not just a convicted fraudster, but also funded Australia's successful crew in the America's Cup and paid far too much for acquiring Channel 9 from Kerry Packer in the days of easy finance.

Subjects are selected as corporate villains based on three criteria: their infamy; compatibility with the subject matter of the lecture and their criminal and/or civil breach of the Corporations Act 2001 (Cth). In terms of compatibility, I attempt to match corporate villains with the cases in which they appear and are discussed in the lecture. Corporate villains have included Emmanuel and Julie Cassimatis, Jodee Rich, Rodney Adler, Ray Williams, Tim Johnston, Steve Vizard, Rene Rivkin, Christopher Skase, John Elliott, Peter Foster and Alan Bond. Students are encouraged to do some research and identify the corporate villain prior to the lecture.

At the beginning of each lecture, I ask the students to reveal the corporate villain and what they know about the person. Students initiate and participate in the story telling process. I acknowledge the students' contributions and incorporate their comments into my story. My story typically follows a chronological path involving the villain's personal and corporate background, brief description of the misconduct and its legal consequences, and postscript or "where are they now?" segment. The additional background information breathes life into the parties to a case. ${ }^{7}$ For example, the story of John Elliott entails his position as CEO of Elders IXL; his presidency of the Liberal Party and the Carlton Football Club; his unsuccessful attempt to buyout Elders IXL; his company taking a majority shareholding in the Water Wheel group of companies and Elliott becoming a non-executive director; his conflict of interest; the collapse of Water Wheel; the subsequent ASIC investigation and court action; and Elliot's bankruptcy and discharge from bankruptcy in 2007. John Elliott's story represents

\footnotetext{
${ }^{5}$ Ibid at 9 .

${ }^{6}$ Ibid at 9 .

${ }^{7}$ A F Moore, 'Contact and concepts: educating students at Jesuit law schools' (2006) 41 Gonzaga Law Review 459 at 472.
} 
a starting point for discussion during that week's lecture of sections $588 \mathrm{G}$ and $588 \mathrm{H}$ of the Corporations Act 2001 (Cth). In some cases, the story telling process is supported by technology such as television clips (Rodney Adler) and radio interviews (John Elliott). The corporate villains segment of the lecture runs for approximately 5-10 minutes.

\section{Corporate Villains: Results}

Student Evaluation of Course (SEC) and Student Evaluation of Teaching (SET) data was obtained in the years 2008 to 2010 . The results suggest that telling the story of a corporate villain each week was a teaching method that enhanced student learning because it engaged students, was relevant to the curriculum and stimulated curiosity in learning the law beyond the prescribed weekly materials. The quantitative data revealed that:

- $96 \%$ of Company Law students surveyed in 2008 and 2009 responded with Good, Very Good or Excellent to the SET question: "How effective was this lecturer in using teaching methods that helped you to learn";

- $99 \%$ of Company Law students surveyed in 2010 responded with Agree or Strongly Agree to the SET question: "The staff member presented material in an interesting way"; and

- $50 \%$ of Company Law students surveyed in the 2008 Logan cohort who provided a comment in response to the open ended SEC question: "aspects which were done well and should be continued" mentioned corporate villains.

The discussion of corporate villains influenced student learning by enabling students to relate the corporate villain's story to the curriculum. Students could see how the law applied to real life situations. In particular, students commented that:

The corporate villains were extremely interesting and put the learning material into perspective; and

The reading guides were great (sic) should be continued, especially each corporate villain that Craig had on each one when matched the relevant topics throughout the semester.

Students repeatedly used the word "interesting" to describe corporate villains. For example, students commented that "the discussion of corporate criminals was interesting and motivating" and "I relly (sic) like the Corporate Villain technique keeps me interested in the course". Further, corporate villains assisted me in transforming student perceptions of company law from boring to interesting:

The lecturer was effective in communicating the subject matter and made a seemingly boring subject surprisingly (sic) interesting and relevant (inclusion of the weekly corporate villains was like my weekly fix of corporate gossip; with mugshots to boot)

Corporate villains also stimulated curiosity in learning more about the law. Students conducted further research about the corporate villains and discussed the corporate villains with colleagues outside the lecture time:

Corporate Villain: this was a brilliant way of creating interest in the weeks topic and caused quite a lot of discussion after the lecture had finished sometimes for days.

... he makes the topics so interesting that you are willing to do some research ... on the internet to find out more. I definitely enjoyed his decriptions (sic) of corporate villains and did some search on the internet about some of them. 
Corporate villains have been adopted and expanded by peers. Ms Jennifer Dickfos, co-author of Focus: Corporations Law $\left(3^{\text {rd }} \text { Edition }\right)^{8}$ and course convenor for the postgraduate offering of company law, successfully adopted corporate villains. Ms Dickfos' words support the qualitative and quantitative evidence above, namely corporate villains is a form of storytelling that influenced, motivated and inspired her students to learn:

The inclusion of the corporate villain made what can be a dry and dull subject most interesting to students. Each lecture the students were asked to name the particular villain and give a brief history of his exploits (no female corporate villains were included-not an oversight on Craig's part but a lack of choice). Students who correctly identified the particular villain were rewarded in turn. My students looked forward to identifying the villain each week. Class discussion regarding both the legal and ethical repercussions of the villains behaviour were often heated and diverse, with students offering to include other corporate villains.

I consider Craig's development of this initiative inspired my students to consider corporate law outside the classroom, motivated them to read more than just the set text and substantially increased their interest in the particular corporate law provisions canvassed. ${ }^{9}$

Ms Dickfos' students, many of whom had previous business experience, went beyond the storytelling process I employ for the undergraduate students by discussing the ethical issues attached to the villain's behaviour and by enabling students to identify other corporate villains.

\section{Conclusion}

Storytelling is a teaching method designed to promote student engagement. The inclusion of an antagonist, the corporate villain, to that story brings popular culture into the classroom and humanises company law in a way which engages students. The defendant becomes a person and that person has an interesting personal and corporate history that students can relate back to the subject matter of company law. But with such a focus on villains, why am I ignoring our heroes? Why not tell stories about ASIC, Australia's enforcement knight, slaying the dragons of the corporate world, or champions of corporate governance or corporate citizenship? I can proffer two reasons. First, company law curriculum and assessment is geared towards the traditional or Socratic method of teaching in which villains are easier to identify. As company law teachers we are more likely to discuss case law involving the transgressions by companies and individuals of the Corporations Act 2001 (Cth) than case studies of good corporate citizenship or governance. The second reason is that popular culture has a greater affinity with villains than heroes. The rogue, baddie, fugitive and heavy is an edgier and more exciting character than a hero. Students (who are immersed in that popular culture) are more likely to be engaged by the story of a corporate villain than hero. It is engagement that stimulates productive learning. By no means am I advocating the removal of heroes of corporate governance and citizenship from the company law curriculum. Rather I posit that storytelling may not be the best method of presenting this material to students.

The issues raised and learning outcomes referred to in this note suggest that storytelling is a teaching method worthy of consideration by academics of all law subjects. In company law, the corporate villain story can take the bore out of an area of law in which its protagonist, the company, has no more than a legal personality.

\footnotetext{
${ }^{8}$ Anderson, Dickfos, Nehme, Hyland and Dahdal, Focus: Corporations Law ( $3^{\text {rd }}$ Edition), Lexis Nexis, 2009.

${ }^{9}$ Excerpt of e-mail Jennifer Dickfos to Craig Cameron, 14 May 2009 at 11:21 pm.
} 